\title{
Occurrence of Clavellisa ilishae (Copepoda: Lernaeopodidae) parasitizing herrings (Actinopterygii: Clupeidae) in Brazil
}

\author{
Ocorrência de Clavellisa ilishae (Copepoda: Lernaeopodidae) parasitando sardinhas \\ (Actinopterygii: Clupeidae) no Brasil \\ Juliana Moreira ${ }^{1}$; Fabiano Paschoal ${ }^{2}$; Anderson Dias Cezar $^{3}$; José Luis Luque ${ }^{4 *}$ \\ ${ }^{1}$ Curso de Pós-graduação em Ciências Veterinárias, Universidade Federal Rural do Rio de Janeiro - UFRRJ, Seropédica, RJ, Brasil \\ ${ }^{2}$ Curso de Pós-graduação em Biologia Animal, Universidade Federal Rural do Rio de Janeiro - UFRRJ, Seropédica, RJ, Brasil \\ ${ }^{3}$ Universidade Castelo Branco - UCB, Rio de Janeiro, RJ, Brasil \\ ${ }^{4}$ Departamento de Parasitologia Animal, Universidade Federal Rural do Rio de Janeiro - UFRRJ, Seropédica, RJ, Brasil
}

Received July 15, 2013

Accepted August 28, 2013

\begin{abstract}
The lernaeopodids are highly specialized copepods which are widely distributed worldwide. In this paper the first record of Clavellisa ilishae Pillai, 1962 in the Neotropical region is documented parasitizing Sardinella brasiliensis from coastal zone of Rio de Janeiro, Brasil.
\end{abstract}

Keywords: Sardinella brasiliensis, ectoparasites, Clavellisa ilishae, Neotropical region.

\section{Resumo}

Os lerneopodídeos são copépodes altamente especializados que estão amplamente distribuídos no mundo. Neste estudo é documentado o primeiro registro de Clavellisa ilishae Pillai, 1962 na regiáo Neotropical, parasitando Sardinella brasiliensis do litoral do Rio de Janeiro, Brasil.

Palavras-chave: Sardinella brasiliensis, ectoparasitos, Clavellisa ilishae, região Neotropical.

Parasitic copepods are common on marine fish, and there is a vast literature describing their taxonomy and the records on several hosts (BOXSHALL; HALSEY, 2004). In the Neotropics, copepods are the second largest parasite group in marine fishes and the third largest group in the freshwater hosts (LUQUE; POULIN, 2007). However, there are few records of parasitic copepods on clupeid fishes in this region, essentially due to lack of parasitological studies of these hosts (LUQUE; TAVARES, 2007).

Sardinella brasiliensis (Steindachner, 1879) is a small pelagic fish, belonging to family Clupeidae, which form large schools, and according to Whitehead (1985) is distributed from Gulf of Mexico, Caribbean, West Indies southward to Brazil and northern Uruguay, but according to Figueiredo and Menezes (1978) the distribution of $S$. brasiliensis is restricted to southwest Atlantic, more specifically from Rio de Janeiro to south Brazil. The Brazilian sardinella is the commercially most important fish on the southeastern Brazilian coast and is used as fresh food, canned, or processed as fishmeal for animal feed, and supports the most important fishery, with total annual catches around 150.000 t (ROSSIWONGTSCHOWSKI et al., 2003; TEODORO et al., 2007).

\footnotetext{
*Corresponding author: José Luis Luque

Departamento de Parasitologia Animal, Universidade Federal Rural do Rio de Janeiro - UFRRJ, CEP 23890-000, Seropédica, RJ, Brasil

e-mail: luqueufrrj@gmail.com
}

Lernaeopodidae is a large and diverse family of highly specialized parasitic copepods, currently comprising 48 genera including Clavellisa Wilson, 1915, which consists of 12 nominal species (GURNEY, 1947; BOXSHALL; HALSEY, 2004). Members of Clavellisa genus are host specific, and many species have been found associated with clupeiform fishes, particularly from Indian waters (RUBEC; HOGANS, 1987; EL-RASHIDY; BOXSHALL, 2010).

One hundred specimens of Sardinella brasiliensis, collected from coastal zone of the State of Rio de Janeiro, Brazil $\left(21-23^{\circ} \mathrm{S}\right.$, $41-45^{\circ} \mathrm{W}$ ) were necropsied between march 2010 and august 2011, to study their biodiversity of metazoan parasites. Four specimens were parasitized by Clavellisa ilishae (Figure 1), indicating a prevalence of $4 \%$. After collection, the copepods were fixed and preserved in ethanol $(70 \% \mathrm{GL})$ and were clarified with lactic acid for identification. The taxonomic determination of the parasites was in accordance with the diagnosis proposed by El-Rashidy and Boxshall (2010). Were collected a total of eleven specimens of $C$. ilishae, with a mean intensity of 2.75 , all attached to the gills, and all copepods were sexually mature females. Specimens of C. ilishae (three females) were deposited in the Crustacea Collection of the National Museum, Rio de Janeiro (MNRJ No 23421).

The body of a lernaeopodid female has the maxillae fused to an anchoring structure known as a bulla, which is attached to the host (PIASECKI et al., 2004). We identified C. ilishae from the 
shape of the trunk, broader than long and laterally rounded, the elongate cephalothorax, details of oral appendages and its short maxillary arms, and by the presence of small caudal rami, flanking the anal laminae, on the posterior margin of the trunk, reported, until the present moment, only on this species. The dimensions of the present specimens are comparable with those given by Pillai (1962), Kensley and Grindley (1973) and by El-Rashidy and Boxshall (2010) (Table 1).

Clavellisa ilishae was originally described by Pillai (1962) and since its description this species has only been recorded parasitizing clupeiform hosts (Ilisha filigera, I. melastoma, Tenualosa ilisha, Sardinops sagax and Sardinella aurita) (KABATA, 1979; PILLAI, 1985; KENSLEY; GRINDLEY, 1973; EL-RASHIDY; BOXSHALL, 2010). The presence of this copepod in $S$. brasiliensis corroborates with the theory of host specificity on the genus by clupeiform fishes proposed by El-Rashidy and Boxshall (2010), which recorded C. ilishae parasitizing the Round sardinella Sardinella aurita in Egypt. Probably the dissemination of $C$. ilishae in the Neotropics occurred through the $S$. aurita, that is widely distributed in this region, inhabiting the continental shelves of the western Atlantic from Massachusetts (USA) throughout the Gulf of Mexico and Caribbean Sea to Rio de Janeiro (Brazil) and the eastern Atlantic at the African coasts, South Africa, and also on Mediterranean and Black Sea (FISCHER, 1978; WHITEHEAD, 1985).

There are no records of parasitic copepods on S. brasiliensis, indeed there are few records of parasitic copepods in clupeid fishes at the Brazilian waters. Montú (1980) described the species Gauchergasilus (= Ergasilus) euripedesi parasitizing Brevoortia
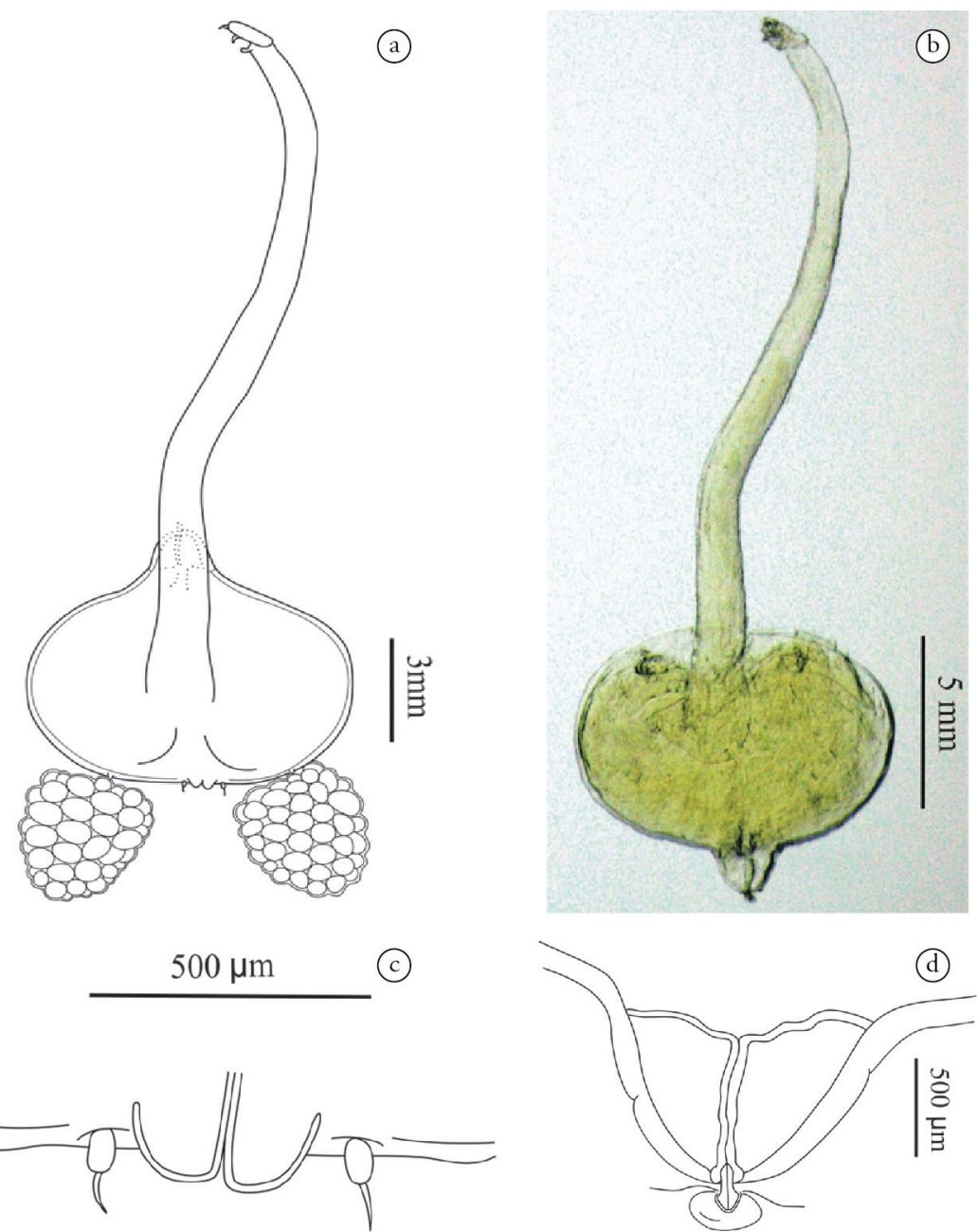

Figure 1. Clavellisa ilishae Pillai, 1962, female. a) Habitus; b) habitus (DIC electron micrograph); c) anal laminae; d) maxillae attached to bulla.

Table 1. Comparison of measures of Clavellisa ilishae Pillai, 1962.

\begin{tabular}{lcccc}
\multicolumn{1}{c}{ Host } & Locality & Cephalothorax & Trunk length & Trunk width \\
\hline Ilisha filigera $^{*}$ & India & $1.9 \mathrm{~mm}$ & $0.6 \mathrm{~mm}$ & $1.0 \mathrm{~mm}$ \\
Sardinops sagax & South Africa & $1.5-2.0 \mathrm{~mm}$ & - & $0.80-1.0 \mathrm{~mm}$ \\
Sardinella aurita*** & Egypt & $2.0-2.75 \mathrm{~mm}$ & $0.50-0.73 \mathrm{~mm}$ & $0.73-1.06 \mathrm{~mm}$ \\
Sardinella brasiliensis & Brazil & $1.17-3.12 \mathrm{~mm}$ & $0.55-1.07 \mathrm{~mm}$ & $0.87-1.5 \mathrm{~mm}$ \\
\hline
\end{tabular}

*Data from Pillai (1962); **Data from Kensley and Grindley (1973); ${ }^{* *}$ Data from El-Rashidy and Boxshall (2010). 
pectinata. Amado and Rocha (1996) described the species Acusicola brasiliensis parasitizing the gill filaments of Lile piquitinga and Opisthonema oglinum.

Lernaeopodids may affect their hosts through pathological effects, sometimes causing slight inflammation where the bulla is inserted into the host, but most damage is caused by the rasping action of the mandibles (FRYER, 1982). The habit to form schools can favor the transmission of some parasites with direct life cycle, such as copepods and monogeneans. Thereby, a massive infestation could seriously damage the host and lead to large economic losses in commercially important fishes as Brazilian sardinella.

\section{References}

Amado MAP, Rocha CEF. New species of parasitic copepods of the genus Acusicola (Poecilostomatoida: Ergasilidae) from gill filaments of coastal and freshwater Brazilian fishes, and proposition of Acusicola rogeri n. sp. for A. tenax sensu Cressey \& Collette (1970). Hydrobiologia 1996; 324(3): 183-193. http://dx.doi.org/10.1007/BF00016390

Boxshall GA, Halsey SH. An introduction to copepod diversity. London: The Ray Society; 2004

El-Rashidy H, Boxshall GA. Parasitic copepods on immigrant and native clupeid fishes caught in Egyptian coastal waters off Alexandria. Syst Parasitol 2010; 76(1): 19-38. PMid:20401576. http://dx.doi. org/10.1007/s11230-010-9230-6

Figueiredo JL, Menezes NA. Manual de Peixes marinhos do sudeste do Brasil. II Teleostei (1). Sáo Paulo: Museu de Zoologia da USP; 1978.

Fischer W. FAO species indentification sheets for fishery purposes. Western Central Atlantic (Fishing Area 31), Vol II. Rome: FAO; 1978.

Fryer G. The parasitic copepoda and Branchiura of British freshwater fishes: A handbook and key. Freshwater Biological Association Scientific Publications; 1982.

Gurney R. Some notes on parasitic Copepoda. J Mar Biol Assoc United Kingdom 1947; 27(1): 133-137. http://dx.doi.org/10.1017/ S0025315400014132
Kabata Z. Parasitic Copepoda of British fishes. Ray Society, London, U.K; 1979.

Kensley B, Grindley JR. South African parasitic Copepoda. Ann S Afr Mus 1973; 62: 69-130.

Luque JL, Poulin R. Metazoan parasite species richness in Neotropical fishes: hotspots and the geography of biodiversity. Parasitology 2007; 134(6): 865-878. PMid:17291392. http://dx.doi.org/10.1017/ S0031182007002272

Luque JL, Tavares LER. Checklist of Copepoda associated with fishes from Brazil. Zootaxa 2007; 1579: 1-39.

Montú M. Parasite copepods of southern Brazilian fishes. I. Ergasilus euripedesi n.sp. (Copepoda: Cyclopoidea). Iheringia, Série Zoologia 1980; 56: 53-62.

Piasecki W, Goodwin AE, Eiras JC, Nowak BF. Importance of copepoda in freshwater aquaculture. Zool Studies 2004; 43(2): 193-205.

Pillai NK. Copepods parasitic on South Indian fishes: Families Lernaeopodidae and Naobranchidae. Journal of the Marine Biological Association of India 1962; 4: 58-94.

Pillai NK. The Fauna of India: Copepod parasites of marine fishes. Calcutta: Zoological Survey of India; 1985.

Rossi-Wongtschowski CLDB, Clemmensen C, Ueberschär B, Dias JF. Larval condition and growth of Sardinella brasiliensis (Steindachner, 1879): preliminary results from laboratory studies. Sci Mar 2003; 67(1): 13-23.

Rubec LA, Hogans WE. Redescription of Clavellisa cordata Wilson, 1915 (Copepoda: Lernaeopodidae) from anadromous clupeids in eastern Canada. Can JZool 1987; 65(6): 1559-1563. http://dx.doi.org/10.1139/ z87-241

Teodoro AJ, Andrade ECB, Mano SB. Avaliação da utilização de embalagem em atmosfera modificada sobre a conservação de sardinhas (Sardinella brasiliensis). Ciênc Tecnol Aliment 2007; 27(1): 158-161. http://dx.doi.org/10.1590/S0101-20612007000100028

Whitehead PJP. Clupeoid fishes of the world (suborder Clupeioidei). An annotated and illustrated catalogue of the herring, sardines, pilchards, sprats, shads, anchovies and wolfherrings. Part 1: Chirocentridae, Clupidae and Pristigasteridae. FAO; 1985. FAO Fisheries Synopsis n. 125 